\title{
MENOLAK MAFIA PERADILAN: MENJAGA INTEGRITAS HAKIM-MENYELARASKAN PERBUATAN DAN NURANINYA ${ }^{1}$
}

\author{
Eman Suparman
}

\author{
* Guru Besar Hukum Acara Perdata Fakultas Hukum UNPAD \\ Korespondensi: eman_professor@yahoo.com \\ Naskah dikirim: 9 Desember 2016 \\ Naskah diterima untuk diterbitkan: 15 Maret 2017
}

\begin{abstract}
Terminology of 'Judicial Mafia' or 'Trial Mafia' ironically has been added into Indonesian dictionary since a long time ago. However, the terminology is not only just a figment or slander. In fact, its present has been confirmed by the establishment of the Judicial Mafia Eradication Task Force by President Susilo Bambang Yudhoyono during his rezim. Lately, some important events have occurred in Indonesian judiciary organs. The events are undeniable facts that it is crystal clear that the process of inquiry, investigation, prosecution, and penitentiary in civil or criminal trial can be manipulated. Based on the author's participatory observation during his service at the Judicial Commission, it is known that the welfare improvement program for judges, which was manifested by the Judicial Commission, Government and Parliament of the Republic of Indonesia in the form of increased allowances of judges, has not been able to significantly erode the corrupt behavior of some unscrupulousgreedy judges.Therefore, in order to respond to the objective conditions that occur lately, the President of the Republic of Indonesia has to 9establish Policy Package on Law Reformation for judicial authorities in Supreme Court. The establishment is a conditio sine qua non to save Indonesian law enforcement conditions which already losing its direction. In conclusion, restructurisation and reformation of the whole field of trial process and also to the whole range of the judicial power can no longer be delayed; otherwise law enforcement in this country cannot survive.
\end{abstract}

Keywords: judicial mafia, total reformation in judiciary field, law policy package.

\footnotetext{
${ }^{1}$ Tulisan ini disampaikan pada Seminar Nasional dalam rangka Dies Natalis yang ke 53 Tahun 2016 Fakultas Hukum Universitas 17 Agustus 1945 (UNTAG) Semarang; bertempat di Aula Fakultas Hukum UNTAG Semarang, Sabtu, 10 September 2016
} 


\begin{abstract}
Abstrak
Kosakata mafia hukum atau mafia peradilan sudah cukup lama menjadi tambahan perbedaharaan Kamus Bahasa Indonesia yang sangat memprihatinkan. Namun demikian kata mafia hukum itu bukan sekedar isapan jempol atau sebuah fitnah, melainkan sudah terkonfirmasi keberadaannya dengan dibentuknya Satuan Tugas Pemberantasan Mafia Hukum oleh Presiden Susilo Bambang Yudhoyono pada masa pemerintahannya. Kejadian demi kejadian yang menimpa lembaga peradilan di Indonesia pada berbagai tingkatan akhir-akhir ini, merupakan fakta yang sulit untuk dibantah bahwa sampai saat ini secara terang benderang dapat disaksikan bahwa kasus hukum itu dapat direkayasa, baik perdata maupun pidana, mulai dari proses penyelidikan, penyidikan, penuntutan hingga lembaga pemasyarakatan. Berdasarakan hasil pengamatan partisipatif selama penulis bertugas di Komisi Yudisial, ternyata upaya Peningkatan Kesejahteraan Hakim yang telah diwujudkan oleh Komisi Yudisial bersama Pemerintah dan Parlemen Republik Indonesia berupa ditingkatkannya tunjangan hakim, ternyata belum signifikan mampu mengikis perilaku korup oknum hakim yang bermental serakah. Oleh karena itu, Presiden Republik Indonesia dalam rangka merespons kondisi objektif yang terjadi akhir-akhir ini, untuk menyelamatkan konsisi penegakan hukum yang sudah terseok-seok ini dan tidak boleh lagi dibiarkan, adalah menjadi conditio sine qua non untuk membuat Paket Kebijakan Reformasi bidang Hukum pada wilayah Penyelenggara Kekuasaan Kehakiman di lingkungan Mahkamah Agung. Kesimpulannya, penataan serta reformasi total bidang peradilan terhadap seluruh jajaran penyelenggara kekuasaan kehakiman sudah tidak dapat lagi ditunda, jika ingin menyelamatkan kondisi penegakan hukum pada bangsa ini.
\end{abstract}

Kata kunci: Mafia hukum, reformasi total bidang peradilan, paket kebijakan hukum

\title{
I. Pendahuluan
}

Praktik penegakan hukum di Indonesia sampai detik ini masih dililit oleh berbagai permasalahan yang menjauhkan hukum dari tujuan utamanya untuk memberikan keadilan, kepastian, dan kemanfaatan bagi masyarakat. ${ }^{2}$ Secara kasat mata publik dapat melihat banyak kasus yang tidak hanya mengusik rasa keadilan masyarakat, namun juga menampakkan wajah yang diskriminatif dalam penegakannya. Salah satu contoh yang cukup dikenal masyarakat dimana terlihat adanya diskriminasi tersebut adalah

\footnotetext{
${ }^{2}$ Dalam Rechtsphilosopie, Radbruch mengemukakan konsep hukum terdiri atas 3 (tiga) elemen yaitu: kegunaan (purposiveness), keadilan (justice) dan kepastian hukum (legal certainty). Heather Leawoods, Gustav Radbruch: An Extraordinary Legal Philosopher, "Journal of Law \& Policy”, Vol. 2, No. 1, 2000, hlm. 498.
} 
perbandingan antara proses hukum terhadap kasus "pencurian" dua buah kapuk randu atau dua buah semangka yang cukup cepat dengan penanganan beberapa kasus korupsi yang sangat lamban dan tidak pernah ada kepastian kapan akan dituntaskan. Hukum dalam tataran inilah yang saat ini dilihat dan dirasakan langsung oleh masyarakat kebanyakan. ${ }^{3}$

Berbagai permasalahan hukum yang oleh sebagian masyarakat diberi label populer dengan sebutan mafia peradilan atau mafia hukum tersebut seolah-olah terkonfirmasi keberadaannya dengan dibentuknya Satuan Tugas Pemberantasan Mafia Hukum oleh Presiden. Ini sesungguhnya merupakan tamparan keras bagi dunia hukum, karena secara legal formal kita berarti telah mengakui bahwa mafia hukum itu ada dan sampai saat ini belum dapat terkikis. ${ }^{4}$ Memang faktanya sampai saat ini secara telanjang kita dapat melihat bahwa kasus hukum itu dapat direkayasa, baik perdata maupun pidana, mulai dari proses penyelidikan, penyidikan, penuntutan hingga lembaga pemasyarakatan. Penerapan pasalpasal hukum dapat dinegosiasikan, rencana penuntutan dapat ditawartawarkan, bahkan hukuman dapat digantikan oleh orang lain. Ujungujungnya, permainan kekuasaan yang menentukan hukum, baik kekuasaan uang ataupun kekuasaan politik. ${ }^{5}$

Berbagai carut marut permasalahan penegakan hukum tersebut semakin rumit mencari pemecahannya karena politik hukum di negara kita pun bisa dikatakan tidak terlalu jelas. Hal itu terlihat misalnya dalam pembuatan KUHAP yang tidak kunjung usai, ${ }^{6}$ ini jelas diakibatkan salah satunya karena orientasi hukum acara kita masih belum jelas kemana arahnya. Selain itu masih lemahnya kesadaran hukum di masyarakat termasuk kesadaran masyarakat atas hak dan kewajiban asasinya secara hukum. ${ }^{7}$ Bahkan yang tidak kalah pentingnya adalah masih tingginya toleransi masyarakat terhadap korupsi birokrasi. ${ }^{8}$

Akhirnya, hukum yang seyogianya memiliki tujuan tertinggi untuk menegakkan keadilan pun ternyata jauh panggang dari api. Aparat penegak hukum justru menjadi bagian dari penyebab buruknya penegakan hukum di

\footnotetext{
${ }^{3}$ Moh.Mahfud MD, Revitalisasi Pancasila Sebagai Cita Negara Hukum, Orasi Ilmiah pada Rapat Senat Terbuka Fakultas Hukum Universitas Gadjah Mada dalam rangka Dies Natalis 65 Tahun Fakultas Hukum Universitas Gadjah Mada, Kamis, 17 Februari 2011 di Gedung I Fakultas Hukum, UGM, Yogyakarta, hlm.2.

${ }^{4}$ Definisi mafia hukum sendiri dinyatakan oleh Daniel S. Lev bahwa the judicial mafia is after all a working system that benefits all its participants. In some ways, in fact, for advocates, who otherwise are excluded from the collegial relationships of judges and prosecutors, it works rather better and more efficiently than the formal system. Satgas Pemberantasan Mafia Hukum, Mafia Hukum (Jakarta: Satgas PMH-UNDP), 2010, hlm. 5.

${ }^{5}$ Moh. Mahfud, Revitalisasi Pancasila Sebagai Cita Negara Hukum..., hlm. 2-3.

${ }^{6}$ Contohnya perdebatan yang setelah sekian lama masih tetap belum ada titik temunya, seperti tentang hakim komisaris atau pra peradilan, wewenang dalam penuntutan, penggunaan prinsip pembuktian terbalik dll.

${ }^{7}$ Ini dapat terlihat dari masih sedikitnya masyarakat yang sadar hak-haknya apabila menjadi pihak yang berperkara di pengadilan. Misalnya, hak untuk mendapatkan penasehat hukum dari negara dalam kasus-kasus yang ancaman hukumannya 5 tahun atau lebih.

${ }^{8}$ Misalnya adanya pembayaran tidak resmi pada proses pembuatan berbagai kartu identitas baik yang menjadi wewenang lembaga pemerintahan maupun lembaga penegak hukum.
} 
negeri ini. ${ }^{9}$ Hakim yang diharapkan sebagai benteng terakhir untuk mewujudkan terpenuhinya rasa keadilan bagi masyarakat melalui putusanputusannya ternyata juga menjadi salah satu pihak yang berkontribusi terhadap buruknya penegakan hukum itu sendiri. Begitu pentingnya peran penegak hukum dalam hal ini hakim mengingatkan kita pada ucapan Taverne, "Berikan pada saya jaksa dan hakim yang baik, maka dengan peraturan yang buruk pun saya bisa membuat putusan yang baik" ${ }^{10}$

Pernyataan legendaris tersebut sungguhlah tepat, sebab hakim memiliki kekuasaan yang sangat besar dan penting dalam menentukan bekerjanya pengadilan. Melalui putusannya seorang hakim dapat mengalihkan hak kepemilikan seseorang, mencabut kebebasan warga negara, sampai dengan penghilangan hak hidup seseorang. Memahami demikian pentingnya profesi hakim dalam penegakan hukum dan keadilan, maka dalam perubahan ketiga UUD 1945, dibentuklah Komisi Yudisial yang dalam konstitusi disebutkan mempunyai tugas dan wewenang utama untuk mengusulkan pengangkatan hakim agung dan mempunyai wewenang lain dalam rangka menjaga dan menegakkan kehormatan, keluhuran martabat, serta perilaku hakim. ${ }^{11}$

\section{Pembentukan Komisi Yudisial sebagai Upaya Pencegahan}

Dibentuknya Komisi Yudisial sebagai lembaga pengawas eksternal bagi penyelenggara kekuasaan kehakiman juga didasarkan pada permasalahan bahwa pengawasan internal yang selama ini dilakukan oleh Mahkamah Agung dianggap tidak cukup optimal dan tidak cukup memenuhi prinsip-prinsip akuntabilitas, independensi dan transparansi. Hal tersebut selain karena adanya semangat membela korps yang cukup tinggi, juga disebabkan rumitnya birokrasi yang harus dilakukan sehingga proses pengawasan hakim dan akses masyarakat untuk melaporkan hakim bermasalah menjadi relatif cukup sulit. Selain itu Komisi Yudisial juga mempunyai tujuan umum untuk memberantas adanya mafia peradilan, meningkatkan independensi hakim dan peradilan serta menjalankan proses pembaruan peradilan. ${ }^{12}$ Padahal jumlah hakim di seluruh Indonesia saat ini mencapai sekitar 8000-an dengan jumlah perkara yang disidangkan pertahunnya lebih kurang rata-rata 3.500.000an. ${ }^{13}$

\footnotetext{
${ }^{9}$ Masyarakat Pemantau Peradilan Indonesia, Lembaga Pengawas Sistem Peradilan Pidana Terpadu (Jakarta: Komisi Hukum Nasional, 2002), hlm. 3.

${ }^{10}$ Satjipto Rahardjo, Hukum Progresif Sebuah Sintesa Hukum Indonesia (Yogyakarta: Genta Publishing, 2009), hlm. 10.

${ }^{11}$ Undang-Undang Dasar Republik Indonesia, Pasal 24B ayat 1.

${ }^{12}$ Asep Rahmat Fajar, The Institutionalization of Public Participation in the Selection of Supreme Court Justices by the Judicial Commission of the Republic of Indonesia -Improving State Institution and Enhancing Civil Society-, (Jakarta:2010), hlm. 17.

${ }^{13}$ Dalam penelitian LeIP menyebutkan bahwa jumlah putusan pada tahun 2007 adalah 3.514.709; Tahun 2008 adalah 3.530.042; Tahun 2009 adalah 3.546.854. Lembaga Kajian dan Advokasi untuk Independensi Peradilan (LeIP), Pembatasan Perkara, Strategi Mendorong Peradilan Cepat, Murah, efisien dan berkualitas (Jakarta, Desember 2010), hlm. 8.
} 
Apabila ditelusuri istilah "pengawasan" sering dipadankan dengan istilah "toezicht" (Belanda), "supervision" (Inggris), dan "control" (Belanda dan Inggris). Pengawasan atau kontrol dapat dilakukan sebelum, sepanjang, dan sesudah suatu kegiatan dilaksanakan. ${ }^{14}$ Pengertian pengawasan (toezicht, supervision) adalah suatu bentuk hubungan dengan legal entity yang mandiri, bukan hubungan internal dari entitas yang sama.

Kebutuhan terhadap pengawasan ternyata tidak hanya diperlukan dalam mengontrol jalannya pemerintahan (eksekutif), tapi juga dibutuhkan dalam mengontrol jalannya sistem peradilan di Indonesia (yudikatif). Pengawasan terhadap lembaga peradilan adalah konsekuensi dari reformasi yang merupakan buah keberhasilan atas desakan masyarakat yang menginginkan terjadinya perubahan pada berbagai aspek di Indonesia. Inti dari reformasi adalah kembali ke cita-cita dasar negara hukum dan demokratisasi, dimana masyarakat dapat berpartisipasi dalam segala aspek, termasuk di dalamnya adalah lembaga peradilan. ${ }^{15}$ Pengawasan terhadap lembaga peradilan yang dimaksud disini adalah lebih menitikberatkan kepada pengawasan terhadap hakim.

Sehubungan dengan berbagai teori pengawasan tersebut, apabila dikaitkan dengan aparat penegak hukum, selain terdapat pengawasan perilaku, makna yang terkandung di dalam pengertian pengawasan tersebut berhubungan erat dengan kesatuan tanggung jawab yudisial (judicial responsibility) yang mengandung tiga dimensi pertanggungjawaban, yaitu: ${ }^{16}$

1. tanggung jawab administrasi (administrative responsibility);

2. tanggung jawab prosedural (procedural responsibility) yang menuntut ketelitian atau akurasi hukum acara yang dipergunakan;

3. tanggung jawab substansi (substantif responsibility) yang berhubungan dengan ketepatan pengkaitan antara fakta dan hukum yang berlaku.

Bertolak dari paparan diatas dapat disarikan bahwa Komisi Yudisial adalah lembaga negara yang mandiri dan lahir dari tuntutan reformasi untuk melakukan reformasi lembaga peradilan, khususnya yang terkait dengan fungsinya untuk mengusulkan pengangkatan hakim agung dan mengawasi hakim agung dan hakim pada badan peradilan di semua lingkungan peradilan yang berada di bawah Mahkamah Agung sebagaimana dimaksud dalam Undang Undang Dasar Negara Republik Tahun 1945. Pengawasan yang dilakukan oleh Komisi Yudisial mencakup pengawasan preventif dan

\footnotetext{
${ }^{14}$ James H. Donnelly, James L. Gobson, dan John M. Ivancevich;dalam Fundamentals of Management (1981) menyebut hal itu Preliminary control, concurrent control dan feedback control. Adapun James A. F. Stoner dan Charles Wankel dalam Management (1986) menyebut ketiga macam kontrol itu Pre-action control, steering control dan post-action control. Taliziduhu Ndraha, Kybernology (Ilmu Pemerintahan Baru), Jilid I (Jakarta: Rineka Cipta, 2003), hlm. 197.

${ }^{15}$ Takdir Rahmadi, Peran dan Fungsi Komisi Yudisial dalam Kekuasaan Kehakiman, Seminar on Comparative Models of Judicial Commissions, Peran Komisi Yudisial di Era Transisi Menuju Demokrasi, Proceeding Seminar, 5 Juli 2010, Jakarta, hlm. 91.

${ }^{16}$ Masyarakat Pemantau Peradilan Indonesia, Lembaga Pengawas Sistem Peradilan Pidana Terpadu (Jakarta: Komisi Hukum Nasional, 2002).
} 
represif dalam rangka menjaga dan menegakkan kehormatan, keluhuran martabat, serta perilaku hakim. Dengan eksistensi dan fungsi yang demikian itu, Komisi Yudisial memegang peranan yang sangat penting dan strategis dalam upaya mewujudkan lembaga peradilan yang mandiri, tidak berpihak, profesional, bertanggungjawab, menjunjung tinggi nilai-nilai keadilan dan kebenaran, serta mampu menegakkan wibawa hukum.

\section{Mengawasi Hakim untuk Menjaga Martabatnya serta Mencegah agar tidak Melakukan Korupsi, Kolusi, dan Nepotisme $(\mathrm{KKN})$}

KKN yang merupakan akronim dari Korupsi, Kolusi, dan Nepotisme, sebagai terminologi dalam kehidupan masyarakat, riwayat kemunculannya relatif masih baru. Orang ramai menyebut istilah KKN kira-kira dalam kurun dua dekade terakhir ini atau tepatnya ketika rezim OrdeBaru hampir berakhir. Sedangkan kata korupsi sebagai bagian dari rangkaian singkatan $\mathrm{KKN}$, istilah maupun pengertiannya telah sangat lama dikenal. Bahkan di Indonesia kata korupsi telah sejak lama menjadi istilah hukum. Setidak-tidaknya istilah korupsi untuk pertama kalinya menjadi istilah hukum sejak dirumuskan dalam Peraturan Penguasa Militer Nomor PRT/PM/06/1957 tentang Pemberantasan Korupsi. ${ }^{17}$ Kemudian pada masa Orde Lama, Pejabat Presiden Republik Indonesia saat itu Djuanda, pada tanggal 9 Juni 1960 pernah menetapkan Peraturan Pemerintah Pengganti Undang-undang Republik Indonesia Nomor 24 Tahun 1960 Tentang Pengusutan, Penuntutan dan Pemeriksaan Tindak Pidana Korupsi. Selanjutnya, komitmen untuk memberantas korupsi ditegaskan kembali dengan diundangkannya Undang-undang Nomor 3 Tahun 1971 Tentang Pemberanatasan Tindak Pidana Korupsi, tanggal 29 Maret 1971. ${ }^{18}$

Adapun kolusi dan nepotisme merupakan gejala amat mutakhir yang muncul di akhir Orde Baru. Oleh karena itu, penyebutan dan popularitas istilah itu di masyarakat relatif masih sangat baru, bahkan hingga tahun 1997 kedua istilah itu belum secara resmi menjadi istilah hukum. Ketika itu masih merupakan istilah umum atau mungkin istilah politis yang berkembang di masyarakat. Istilah kolusi dan nepotisme secara resmi digabungkan dengan istilah korupsi dalam satu rangkaian istilah dan disingkat KKN secara formal dilakukan melalui TAP MPR Nomor XI/MPR/1998 tanggal 13 November 1998 tentang "Penyelenggaraan Negara yang Bersih dan Bebas Korupsi, Kolusi, dan Nepotisme." Sejak saat itulah KKN sebagai istilah politis resmi dinyatakan

\footnotetext{
${ }^{17}$ Hermien Hadiati Koeswadji, Korupsi di Indonesia - Dari Delik Jabatan ke Tindak Pidana Korupsi. Bandung: Citra Aditya Bakti, 1994, hlm. 33.

${ }^{18}$ Paling tidak sampai sekarang Undang-Undang Nomor 3 Tahun 1971 telah mengalami dua kali perubahan. Tahun 1999 dengan Undang-undang Nomor 31 Tahun 1999 dan kemudian diubah lagi dengan Undang-undang Nomor 20 Tahun 2001 Tentang Perubahan Undang-Undang Nomor 31 Tahun 1999 Tentang Pemberantasan Tindak Pidana Korupsi.
} 
oleh produk hukum Lembaga Tertinggi Negara menjadi istilah yang diarahkan untuk menjadi istilah hukum.

Pada era pemerintahan transisi di bawah Presiden BJ Habibie, istilah $\mathrm{KKN}$ diresmikan menjadi istilah hukum dengan diundangkannya Undang-Undang Nomor 28 Tahun 1999, tanggal 19 Mei 1999 Tentang "Penyelenggara Negara yang Bersih dan Bebas dari Korupsi, Kolusi, dan Nepotisme". Di dalam Bab I Ketentuan Umum, Pasal 1 Undang-Undang tersebut, pengertian KKN secara jelas diuraikan per-definisi. Uraian mengenai pengertian dari masing-masing istilah dimaksud dapat diketahui berikut ini:

1. Korupsi adalah tindak pidana sebagaimana dimaksud dalam ketentuan peraturan perundang-undangan yang mengatur tentang tindak pidana korupsi.19

2. Kolusi adalah permufakatan atau kerja sama secara melawan hukum antar-Penyelenggara Negara atau antara Penyelenggara Negara dan pihak lain yang merugikan orang lain, masyarakat, dan atau Negara.

3. Nepotisme adalah setiap perbuatan Penyelenggara Negara secara melawan hukum yang menguntungkan kepentingan keluarganya dan atau kroninya di atas kepentingan masyarakat, bangsa, dan negara.

Sedangkan kata "integritas" sebagaimana dipergunakan dalam judul tulisan ini, di dalam Kamus Bahasa Indonesia memiliki arti "jujur dan dapat dipercaya". Jujur yang berarti lurus hati, tidak curang, tulus, ikhlas. Jadi yang dimaksud dengan "integritas hakim" dalam judul makalah ini adalah sosok seorang hakim yang memiliki ciri-ciri sebagai pribadi manusia yang jujur, lurus hati, tidak curang, tulus, dan ikhlas dalam melakukan pengabdiannya sebagai hakim. Di samping itu tentu sebagai hakim dia juga harus pandai, memiliki keberanian, teguh pendirian dalam kebenaran, arif, dan bijaksana.

Mengapa dalam menangani kasus-kasus KKN sosok figur seorang hakim yang memiliki integritas harus lebih diutamakan? Oleh karena sebagaimana telah diutarakan, bahwa seorang hakim sebagai salah satu unsur penyelenggara negara ${ }^{20}$ sangat memainkan peran sentral dalam menentukan dapat atau tidaknya seseorang terdakwa kasus KKN dijatuhi pidana sesuai dengan aturan yang berlaku sebagaimana dikehendaki oleh seluruh rakyat Indonesia.

${ }^{19}$ Untuk memahami Rumusan delik Korupsi, lihat Pasal 2 dan Pasal 3 Undangundang Nomor 31 Tahun 1999. Kedua pasal tersebut disadur dari Pasal 1 ayat (1) sub a dan sub b Undang-Undang Nomor 3 Tahun 1971 Tentang Pemberantasan Tindak Pidana Korupsi, LN 1971 Nomor 19.

${ }^{20}$ Lihat Pasal 2 angka 5 Undang-Undang Nomor 28 Tahun 1999 Tentang "Penyelenggara Negara yang Bersih dan Bebas dari Korupsi, Kolusi, dan Nepotisme. Dalam penjelasannya disebutkan yang dimaksud dengan "Hakim" dalam ketentuan ini meliputi Hakim di semua tingkatan Pengadilan. 
Persoalannya memang sangat tidak sederhana dan tidak mudah dalam menggiring pelaku tindak pidana $\mathrm{KKN}$ ini. Oleh karena para pelaku KKN dalam kehidupannya di masyarakat pada umumnya memiliki segalagalanya, baik status sosial-ekonomi maupun status sosial-politik yang diyakini keunggulannya dibandingkan dengan masyarakat kebanyakan. Kondisi objektif itu pun tentu tidak dapat dinafikan sebagai satu kendala tersendiri yang hanya mungkin dapat diatasi oleh seseorang yang memiliki integritas yang utuh dan paripurna, tatkala dia akan bertugas mengadili pelaku tindak pidana KKN. Tanpa integritas dan bekal moral personal yang tangguh memang cukup berat jika harapan penanganan kasus-kasus KKN semata-mata digantungkan pada prosedur hukum yang berlaku dengan keadaan sumberdaya manusia peradilan atau para hakim yang kondisinya masih seperti sekarang ini.

Hadirnya Komisi Yudisial tidak lepas dari keinginan bangsa Indonesia dalam menegakkan konsep negara hukum yang sudah kita citacitakan sejak diproklamasikan kemerdekaan oleh para founding fathers Indonesia. Mengusulkan hakim agung dan mengawasi perilaku dalam rangka menjaga dan menegakkan kehormatan serta keluhuran martabat hakim merupakan kewenangan konstitusional dari Komisi Yudisial. Dalam hal ini kewenangan menjaga dan menegakkan kehormatan serta keluhuran martabat hakim harus diartikan sebagai suatu kewenangan untuk mengawasi perilaku hakim baik di dalam maupun diluar pengadilan.

Pengawasan terhadap kewenangan hakim perlu dilakukan dalam rangka membatasi kekuasaannya agar tidak bertindak sewenang-wenang. Salah satu cara adalah melakukan pengawasan hakim dengan menunjukkan keteladanan dan menekankan pada rasa malu untuk membuat kesalahan. Inilah kemudian yang disebut dengan "Mengawasi Hakim untuk Menjaga Martabatnya.” Melalui model pengawasan ini diharapkan hakim akan merasa malu dan tidak berani melawan hati nuraninya untuk bertindak tercela atau bertindak diluar kode etik dan pedoman perilaku hakim. Hakim yang ideal setidaknya harus memiliki karakter sebagaimana yang dicontohkan oleh Rasulullah Muhammad SAW yakni keteladanan dalam wujud karakter shidiq, amanah, fathonah, dan tabligh. Oleh karena itu, konsep pengawasan hakim bermartabat harus dimulai dengan tauladan bagaimana sebenarnya menjadi hakim ideal. Mind set hakim ideal diharapkan dapat merubah budaya hukum hakim kita yang selama ini kehilangan "rasa malu" melakukan sesuatu yang salah atau melanggar kode etik dan pedoman perilaku hakim (KEPPH).

\section{Mengembalikan Kehormatan Hakim Yang Mulia}

Pengawasan eksternal yang dilakaukan oleh Komisi Yudisial selama ini, sejatinya agar masyarakat memiliki keberanian menyampaikan keluh kesahnya kepada lembaga di luar struktur resmi lembaga yudikatif. Eksistensinya pun semata-mata dimaksudkan untuk menjaga dan 
menegakkan kehormatan, keluhuran martabat, serta perilaku hakim dalam rangka mewujudkan kebenaran dan keadilan berdasarkan ke-Tuhanan Yang Maha Esa. Melalui kehormatan dan keluhuran martabatnya itu kekuasaan kehakiman yang merdeka dan bersifat imparsial (independent and impartial judiciary) yang diimbangi oleh prinsip akuntabilitas kekuasaan kehakiman, baik dari segi hukum maupun segi etika diharapkan dapat diwujudkan. ${ }^{21}$ Menjadi jelas bahwa sejalan dengan pengawasan oleh Komisi Yudisial itu, hakim dituntut untuk menjunjung tinggi kehormatan, keluhuran martabat, serta perilaku dalam melaksanakan tugas dan wewenangnya sebagai penyelenggara kekuasaan kehakiman. Hal ini sebagaimana tercermin dalam kode etik dan pedoman perilaku hakim, bahwa: ${ }^{22}$

Pada giliranya pengawasan itu tidak lain untuk mengembalikan kehormatan Hakim yang Mulia. Oleh karena sebutan hakim "Yang Mulia" (The honorable justice) itu memang telah dilekatkan kepada profesi hakim. Kehormatan adalah kemulian atau nama baik yang senantiasa harus dijaga dan dipertahankan dengan sebaik-baiknya oleh para Hakim dalam menjalankan fungsi pengadilan. Kehormatan hakim itu terutama terlihat pada putusan yang dibuatnya, dan pertimbangan yang melandasi, atau keseluruhan proses pengambilan keputusan yang bukan saja berlandaskan peraturan perundang-undangan, tetapi juga rasa keadilan dan kearifan yang timbul dari masyarakat. Sebagaimana halnya kehormatan, keluhuran martabat juga merupakan tingkat harkat kemanusiaan atau harga diri yang mulia yang sepatutnya tidak hanya dimiliki, tetapi harus dijaga dan dipertahankan oleh Hakim melalui sikap tindak atau perilaku yang berbudi pekerti luhur. Hanya dengan sikap tindak atau perilaku yang berbudi pekerti luhur itulah kehormatan dan keluhuran martabat Hakim dapat dijaga dan ditegakkan.

Kode etik profesi merupakan inti yang melekat pada suatu profesi, ia adalah pedoman perilaku yang memuat nilai etika dan moral. Hakim dituntut untuk profesional dan menjunjung etika profesi. Profesionalisme tanpa etika menjadikannya "bebas sayap" (vluegel vrij) dalam arti tanpa kendali dan tanpa pengarahan. Sebaliknya, etika tanpa profesionalisme menjadikannya "lumpuh sayap" (vluegel lam) dalam arti tidak maju bahkan tidak tegak. Pelanggaran atas suatu kode etik profesi tidaklah terbatas sebagai masalah internal lembaga peradilan, tetapi juga merupakan masalah masyarakat.

\footnotetext{
${ }^{21}$ Menurut Shetreet independensi peradilan terbagi menjadi 4 jenis, yaitu substantive independency (independency in deciding the case), personal independency (independency in term of office and tenure), internal independency (independency from superior and co-worker) and collective independency (court independency in administration, budgeting and human resources development). Mahkamah Agung, Cetak Biru Pembaruan Mahkamah Agung Republik Indonesia (Jakarta: MARI, 2003), hlm. 7.

${ }^{22}$ Keputusan Bersama Ketua Mahkamah Agung dan Ketua Komisi Yudisial No: 047/KMA/SKB/IV/2009 dan No: 02/SKB/P.KY/IV/2009 Tentang Kode Etik dan Pedoman Perilaku Hakim.
} 
Berdasarkan narasi yang terdapat dalam kode etik dan pedoman perilaku di atas, jelaslah bahwa selain wewenangnya yang besar, tanggung jawab yang diemban oleh Komisi Yudisial pun sangatlah berat. Apalagi selain wilayah Indonesia yang sangat luas, jumlah hakim yang perlu diawasi pun dapat dikategorikan luar biasa banyak. Oleh karena itu, Komisi Yudisial dituntut untuk berpikir secara kreatif guna mencari strategi yang tepat agar penjalanan tugas dan wewenangnya tersebut dapat berjalan secara optimal. Salah satu ide kreatif yang saat ini sudah dilakukan adalah dengan membuat Kantor Penghubung di daerah-daerah sebagai mandat dari Undang-Undang Nomor 18 Tahun 2011. Di samping itu juga tetap dipertahankannya keberadaan jejaring yang berasal dari komunitas masyarakat sipilyang terdiri atas perguruan tinggi, lembaga swadaya masyarakat, organisasi keagamaan, dan organisasi masyarakat. ${ }^{23}$

Pembentukan jejaring selain berangkat dari kesadaran data-data faktual tentang besar wilayah dan jumlah hakim yang diawasi di atas, juga berangkat dari pemikiran bahwa salah satu faktor penyebab terjadinya apa yang disebut dengan mafia peradilan adalah karena kurangnya partisipasi publik dalam menjaga dan menegakkan kehormatan, keluhuran martabat serta perilaku hakim. Kesadaran ini bertolak dari dua hal dasar, bahwa di satu sisi mafia peradilan pada akhirnya akan menempatkan masyarakat sebagai korban -dengan harga yang sangat mahal- sementara di sisi lain terwujudnya peradilan yang independen, imparsial, profesional, serta yang memungkinkan perlakuan yang sama bagi semua pihak di muka hukum (equality before the law)juga menuntut adanya peran publik yang optimal. ${ }^{24} \mathrm{Di}$ sisi lain hakim selaku pejabat negara yang mempunyai wewenang sangat besar akan merasa bahwa dirinya tidak bekerja di ruang nyaman (comfort zone) yang bebas dari pengawasan siapapun sehingga dia bisa bertindak seenaknya. ${ }^{25}$

Hal ini sejalan dengan apa yang dikatakan oleh salah seorang akademisi yang menyatakan bahwa Komisi Yudisial dipastikan mendapat capaian positif bila indikator berikut terpenuhi; (1) Meningkatnya pengawasan proses peradilan secara transparan; (2) Meningkatnya partisipasi masyarakat dalam rangka pengawasan dan pembenahan terhadap sistem manajemen dan administrasi peradilan secara terpadu; (3)

\footnotetext{
${ }^{23}$ Dalam tulisannya, Flyvbjerg menyatakan bahwa in Habermas theory the civil society consists of churches, cultural associations, sport clubs and debating societies to independent media, academies, groups of concerned citizens, grass-roots initiatives and organizations of gender, race and sexuality. Bent Flyvbjerg, Habermas and Foucault: Thinkers for Civil Society? The British Journal of Sociology, Vol. 49, No. 2 (Blackwell Publishing, 1998), hlm. 210.

${ }^{24}$ Peran serta masyarakat diakui memiliki peran penting dalam upaya pencegahan dan penegakan hukum terhadap tindak pidana korupsi. Hal ini diakui dalam Konvensi PBB melawan korupsi 2003 (UN Convention Against Coruption,2003) dan dalam Undangundang No. 31 Tahun 1999 sendiri. Undang-undang ini memberi kebebasan kepada masyarakat untuk mencari, memperoleh, dan memberikan informasi bahwa di suatu daerah atau instansi telah terjadi praktik korupsi.

${ }^{25}$ Asep Rahmat Fajar, The Institutionalization of Public Participation ..., hlm. 21.
} 
Tersusunnya sistem rekruitmen dan promosi yang lebih ketat; (4) Berkembangnya pengawasanterhadap proses rekruitmen dan promosi, dan (5) Meningkatnya kesejahteraan hakim melalui peningkatan gaji dan tunjangan-tunjangan lainnya. ${ }^{26}$

\section{Hakim dalam Pusaran Korupsi di lingkungan Lembaga Peradilan (Judicial Corruption)}

Bagaikan ceritera yang tidak berkesudahan, hukum tidak lagi menjadi dasar bagi hakim serta aparatur peradilan lainnya dalam mengakkan keadilan, hal itu terbukti dari banyaknya kasus yang melibatkan hakim serta jajaran aparatur peradilan yang secara sengaja menjadikan kasus-kasus hukum yang sedang ditangani sebagai "proyek" oleh penegak hukum itu sendiri. Bahkan tragisnya penegak hukum itu sendiri yang melakukan kegiatan tersebut yang sering serta lazim dikatakan sebagai mafia peradilan.

Dalam Pelatihan Anti Mafia Peradilan, KP2KKN (Komite Penyelidikan dan Pemberantasan Korupsi, Kolusi dan Nepotisme, 2006), memberikan definisi Mafia Peradilan sebagai berikut:"Perbuatan yang bersifat sistematis, konspiratif, kolektif, dan terstruktur yang dilakukan oleh aktor tertentu (aparat penegak hukum dan pencari keadilan) untuk memenangkan kepentingannya melalui penyalahgunaan wewenang, kesalahan administrasi, dan perbuatan melawan hukum yang mempengaruhi proses penegakan hukum sehingga menyebabkan rusaknya sistem hukum dan tidak terpenuhinya rasa keadilan."27

Mafia Peradilan atau dengan sebutan lain Mafia Hukum di Indonesia memang terkonfirmasi keberadaannya. Salah satu buktinya adalah pada masa pemerintahan Presiden Susilo Bambang Yudhoyono pernah dibentuk Satuan Tugas Pemberantasan Mafia Hukum dengan Keppres No. 37 Th 2009. Itu artinya, praktik Mafia Hukum memang terjadi di sepanjang proses penegakan hukum, mulai dari proses penyelidikan, penyidikan, penuntutan, proses pemeriksaan di pengadilan, sampai dengan dijalaninya masa pemidanaan di lembaga pemasyarakatan, itu memang nyata keberadaannya. Ironisnya sampai hari ini kisah adanya Mafia Hukum di Indonesia masih belum berakhir.

Tampaknya berbagai upaya dari banyak pihak masih belum bisa mengubah paradigma berfikir para aparatur penegak hukum di Indonesia untuk tidak menyalahgunakan wewenangnya meski telah diupayakan tingkat kesejahteraan hidupnya sekalipun. Oleh karena ternyata, hasil akhir dari upaya mensejahterakan hakim saja contohnya, masih belum berbanding lurus dengan perilaku yang ditampilkannya oleh sejumlah

${ }^{26}$ A. Ahsin Thohari, Komisi Yudisial dan Reformasi Peradilan (Jakarta: ELSAM, 2004), hlm. 196-197.

${ }^{27}$ Beni Prawira Candra Jaya, Mafia Peradilan Budaya atau Dosa, www.hukumpedia.co, September 2014. 
oknum hakim. Seharusnya, semakin besar take home pay para hakim, akan semakin terjamin kesejahteraan hidupnya, maka akan semakin baik pula etika serta perilaku hidupnya dalam menjalankan tugas-tugas Illahiah dalam memeriksa, mengadili, serta memutus perkara yang diamanahkan kepada mereka. Nyatanya memang masih jauh api dari panggang. Harapan seluruh rakyat Indonesia terhadap integritas serta akuntabilitas para hakim dan jajaran aparatur peradilan pada umumnya, masih perlu waktu untuk mewujudkannya.

Realitas tersebut membuat kepercayaan masyarakat terhadap para penegak hukum masih terus dan semakin merosot tajam. Fakta-fakta tersebut mengakibatkan hilangnya harapan masyarakat akan adanya kepastian hukum dalam setiap permasalahan hukum yang dihadapi. Rentetan kasus yang terjadi akhir-akhir ini menunjukan betapa praktik korupsi yudisial masih berlangsung dan masih sistemik, masif, dan mengakar. Jika berkaca pada jumlah pengadilan diseluruh Indonesia yang mencapai 825 pengadilan (laporan tahunan MA tahun 2015) maka potensi penyimpangan juga sangat besar. Belum lagi persoalan pengawasan yang lemah, semakin memperbesar potensi korupsi di tubuh pengadilan.

Satjipto Rahardjo ${ }^{28}$ mengemukakan "Penegakan hukum selalu akan melibatkan manusia di dalamnya dan dengan demikian akan melibatkan tingkah laku manusia juga." Di Indonesia, perhatian terhadap faktor manusia yang terlibat dalam proses penegakan hukum seperti halnya hakim belum berkembang sama sekali. Pembicaraan tentang sosok hakim sebagai salah satu bagian dari keseluruhan aparat penegak hukum dalam proses peradilan, tentu saja merupakan bagian dari "proses sosial" 29 yang lebih besar. Oleh sebab itu, tatkala merebak isu KKN terjadi pada lembaga pengadilan dan menimpa sejumlah hakim, maka "...hakim dan lembaga peradilan harus dikaji sebagai bagian atau kelanjutan dari pikiran-pikiran dan nilai-nilai yang berlaku dalam masyarakat. Proses yang terjadi dalam ruang pengadilan tidak dapat dilepaskan dari keseluruhan proses sosial yang berjalan dalam masyarakat. Kecenderungan-kecenderungan yang terdapat pada suatu masa tertentu akan mengimbas pula kepada para hakim pengadilan, sehingga sulit bagi hakim untuk menolak dominasi yang demikian itu." 30

Apabila uraian di atas dihubungkan dengan isu KKN yang diduga telah melanda hakim dan lembaga pengadilan serta aparat penegak hukum pada umumnya, boleh jadi semua itu karena KKN yang terjadi di Indonesia merupakan bagian dari proses sosial yang berjalan dalam masyarakat. Merujuk pada apa yang diteorikan Talcott Parsons yang kemudian diikuti Julius Stone yang menyebut adanya expected reactions yang datangnya

\footnotetext{
${ }^{28}$ Satjipto Rahardjo, Masalah Penegakan Hukum suatu tinjauan sosiologis. Bandung: Sinar Baru,TT, hlm. 11.

29 "Proses Sosial adalah hubungan timbal balik antara bidang-bidang kehidupan dalam masyarakat, melalui interaksi antara warga masyarakat atau kelompok”. Lihat Soerjono Soekanto, Kamus Sosiologi (edisi baru), Jakarta: Rajawali, 1983, hlm. 396.

${ }^{30}$ Ibid., hlm. 75-76, dan 79.
} 
dari masyarakat. Seorang hakim tidak dapat bertindak mengikuti keinginannya sendiri, melainkan didisiplinkan oleh sistem expected reactions tersebut. Hal ini disebabkan tugas-tugas dan pekerjaan-pekerjaan yang sehari-harinya harus dijalankan oleh seorang hakim dilingkungi oleh harapan-harapan serta tuntutan-tuntutan para anggota masyarakat yang diorganisasi di sekitar tugas-tugas hakim tersebut.

Seperti diutarakan Satjipto Rahardjo selanjutnya, bahwa "...bagaimana pun secara yuridis formal ditentukan, bahwa hakim itu harus bebas dalam menentukan keputusannya, namun apabila tindakan itu dikaitkan pada kehidupan sosial yang lebih besar yang melingkupinya, maka diketahui, bahwa peranan yang dapat dimainkan oleh seorang hakim dalam masyarakat itu sangat ditentukan oleh adanya beban pengaruh, berupa harapan dan tuntutan yang datang dari masyarakat itu sendiri." Beban pengaruh, harapan, dan tuntutan dari masyarakat bagi penegak hukum kadang-kadang datangnya itu tidak menunjang bagi pelaksanaan tugas penegakan hukum. Sebagai contoh umpamanya, rendahnya kesadaran hukum masyarakat dan berlangsungnya praktik-praktik KKN (suapmenyuap dan sogok menyogok) dalam praktik penegakan hukum. ${ }^{31}$

Oleh karena itu, kelompok masyarakat yang memiliki sumberdaya ekonomi kuat, politik dan kekuasaan, tentu sangat membawa pengaruh terhadap proses penegakan hukum di pengadilan. Atau dengan kata lain kelompok masyarakat dengan status sosial tinggi, yang didukung oleh kondisi ekonomi kuat, tentu lebih memiliki akses untuk mendapatkan keadilan. ${ }^{32}$

Tantangan eksternal lain yang datang dari masyarakat dalam proses penegakan hukum adalah kurangnya kepercayaan kepada penegak hukum, merosotnya wibawa hukum, dan melembaganya budaya hedonistik dan konsumeristik dalam masyarakat. Budaya hedonistik dan konsumeristik jika sempat menghinggapi perilaku hakim maupun penegak hukum yang lainnya hasilnya sungguh sangat membahayakan. Masalahnya seperti dikonstatir oleh Chambliss \& Seidman, yang dituturkan kembali oleh Satjipto Rahardjo, bahwa “...sama halnya dengan orang-orang lain, hakim juga menginginkan status, kekuasaan, dan kedudukan istimewa (privilege) yang semakin meningkat di masyarakat. Dalam kedudukannya yang demikian itu ia akan terlibat dalam suasana kehidupan golongan atas atau elit. Menghadiri acara-acara minum-minum, menjadi anggota di klub-klub, mengikuti pertemuan-pertemuan politik, merupakan bagian dari kegiatankegiatan sosial yang harus dilakukannya. Dengan demikian ia akan mengalami pergaulan yang erat dengan orang-orang yang mempunyai kekuasaan dan orang-orang kaya. Di sini pengaruh orang-orang tersebut

\footnotetext{
${ }^{31}$ Salman Luthan \& Agus Triyanta, "Pengembangan Sumber Daya Manusia Aparat Keadilan”; di dalam JURNAL HUKUM, No. 9 Vol. 4, Tahun 1997, hlm. (54-62) 57-58.

${ }^{32}$ Ibid., hlm. 61 .
} 
dengan mudah akan memasuki pikiran hakim melalui percakapanpercakapan informal yang dilakukan di situ". 33

Jika hakim telah seperti itu kondisinya, karena dihinggapi suatu pemahaman yang menganggap bahwa kesenangan dan kenikmatan adalah tujuan utama dalam hidup, maka sikap yang demikian itu telah memberi andil cukup besar bagi hilangnya penghayatan terhadap cita-cita profesi dan rusaknya moralitas personal seorang hakim.

Sebagian rakyat Indonesia tentu tidak akan melupakan apa yang telah diperjuangkan Hakim Agung Adi Andojo Soetjipto ketika beliau bertugas di Mahkamah Agung dalam membongkar kasus kolusi yang terjadi di Mahkamah Agung dalam kasus Gandhi Memorial School. ${ }^{34}$ Demikian pula halnya dengan kasus dugaan KKN yang menimpa lembaga peradilan tertinggi negeri ini. Dua orang hakim agung yang masih aktif dan seorang hakim agung purna tugas disangka telah menerima suap bernilai puluhan juta rupiah berdasarkan laporan yang masuk dari saksi pelapor sebagai korbannya. Isue itu menambah deretan panjang kasus-kasus suapmenyuap, kolusi (KKN) yang terjadi di lingkungan peradilan di Indonesia.

Yasonna Laoly dalam sebuah tulisannya seperti memberikan penegasan tentang apa yang sudah berlangsung sekian lama, yaitu bahwa "bagi sebagian besar praktisi hukum, dugaan adanya kolusi, bahkan korupsi [KKN], di lingkungan peradilan bukanlah suatu yang aneh atau mengejutkan. Sudah tidak menjadi rahasia di kalangan pengacara, bahwa mereka tidak boleh bergantung hanya kepada argumentasi-argumentasi juridis untuk memenangkan perkara yang mereka tangani di pengadilan. Pendekatan-pendekatan "non-juridis" sangat diperlukan, bahkan tidak jarang lebih menentukan dari faktor-faktor juridis." 35

Jika demikian keadaannya, cukup relevan apabila dalam rangka penanganan kasus-kasus $\mathrm{KKN}$ di Indonesia integritas hakim menjadi syarat mutlak yang harus dipenuhi. Oleh karena sangat boleh jadi tidak banyaknya atau bahkan dibebaskannya pelaku tindak pidana KKN oleh hakim, disebabkan di lingkungan peradilan sendiri berlangsung praktikpraktik KKN.

Seperti diketahui bersama, kasus pemalsuan putusan Mahkamah Agung yang pernah menghebohkan masyarakat pencari keadilan, adalah bukti lain adanya KKN di lingkungan peradilan. Bukti KKN paling konkrit yang dilakukan hakim di pengadilan dijumpai tatkala pada akhir tahun 1970-an hingga awal tahun 1980-an Pemerintah Orde Baru menggelar Operasi Tertib Pusat (Opstibpus). Ketika itu banyak hakim yang kena jaring operasi tersebut karena tertangkap basah menerima uang suap di

\footnotetext{
${ }^{33}$ Satjipto Rahardjo, Masalah Penegakan Hukum suatu tinjauan sosiologis. Bandung: Sinar Baru,TT, hlm. 85-86.

${ }^{34}$ Untuk mengetahui secara kronologis terjadinya kasus tersebut, Baca: H. Adi Andojo Soetjipto, "Uraian Secara Kronologis Terjadinya Masalah Kolusi di Mahkamah Agung Republik Indonesia”; di dalam Aldentua Siringoringo \& Tumpal Sihite, Menyingkap Kabut Peradilan ...Op. Cit., hlm. 53-87.

${ }^{35}$ Yasonna H. Laoly. “Kolusi... dalam Menyingkap Kabut...Loc. Cit., hlm. 17.
} 
kantornya. ${ }^{36}$ Ada satu contoh kasus yang dikemukakan, seorang hakim meminta uang suap kepada seorang nyonya sebesar 50 juta rupiah untuk memenangkan perkaranya. ${ }^{37}$ Bahkan pada dekade itu pernah ada seorang hakim pria senior yang karena terbukti meminta dan menerima uang suap, akhirnya hakim tersebut diadili dan dijatuhi pidana penjara serta diberhentikan dengan tidak hormat dari jabatannya sebagai hakim.

Apabila demikian kondisinya, adalah dapat dimengerti jika program menyeret para pelaku KKN untuk diadili dan dipidana sedemikian sulitnya. Masalahnya seperti telah diutarakan di muka bahwa para pelaku KKN itu secara sosial-ekonomi maupun politis memiliki status dan posisi yang lebih unggul segala-galanya di masyarakat. Harta benda yang melimpah dari hasil KKN bisa saja mereka gunakan untuk berbagai kepentingan, termasuk tidak mustahil digunakan untuk menyuap polisi, jaksa, maupun hakim. Oleh karena pelaku KKN meyakini bahwa ketiga aparatur negara itu, yakni: polisi, jaksa, maupun hakim adalah serangkaian aparatur negara yang sangat berperan langsung dalam menangani kasus-kasus KKN hingga para pelakunya dijebloskan ke dalam penjara. Adalah sesuatu yang normal sebagai manusia jika pelaku tindak pidana KKN yang dilaporkan oleh pihak pelapor (baca: korbannya atau orang-orang yang memiliki cukup bukti) kepada aparat penyidik, kemudian pelaku KKN itu berupaya menyuap pihak aparat penyidik. Betapa pun harga diri dan kehormatan dia (pelaku KKN) akan diupayakan untuk diproteksi sedemikian rupa dengan tumpukan harta kekayaan yang mereka kuasai meski itu dikumpulkan dari hasil KKN.

Bila moralitas dan integritas aparat penyidik berada dalam posisi yang lemah, sudah dapat dipastikan dia akan hanyut dengan iming-iming sejumlah pemberian dari tersangka tindak pidana KKN tersebut. Pada tahap awal jika demikian kondisinya penegakan hukum terhadap kasuskasus KKN sudah kehilangan daya. Oleh karena itu, seorang tokoh pejuang penegakan hukum yang sangat gigih, Baharudin Lopa, dalam satu tulisannya, mengutarakan: "Ada tiga syarat untuk memungkinkan tegaknya hukum dan keadilan di masyarakat. Pertama, adanya peraturan hukum yang sesuai dengan aspirasi masyarakat. Kedua, adanya aparat penegak hukum yang profesional dan bermental tangguh atau memiliki integritas moral terpuji. Ketiga, adanya kesadaran hukum masyarakat yang memungkinkan dilaksanakannya penegakan hukum." 38

Faktor kedua yang dikemukakan Lopa, menyangkut integritas dan moral terpuji, ternyata merupakan unsur yang sangat langka pada dewasa ini, tidak terkecuali juga para aparatur di pengadilan termasuk para hakim. Akibat merosotnya komitmen moral terhadap cita-cita profesi yang dapat

\footnotetext{
${ }^{36}$ Yasonna H. Laoly, Op. Cit., hlm. 19.

${ }^{37}$ Syed Hussein Alatas, Korupsi: Sifat, Sebab, dan Fungsi. Jakarta: LP3ES, 1987, hlm. 108

${ }^{38}$ Baharudin Lopa, Permasalahan Pembinaan dan Penegakan Hukum di Indonesia. (cetakan I), Jakarta: Bulan Bintang, 1987, hlm.3-4.
} 
diamati dari makin melembaganya penyelewengan cita-cita profesi, baik melalui praktik dagang hukum, suap menyuap, maupun kolusi. "Sudah menjadi rahasia umum bahwa putusan hakim bisa diatur (dikompromikan) sesuai permintaan pihak yang berperkara dengan kompensasi sejumlah uang. Tolok ukur uang kompensasi tergantung kepada bobot kasus (nilai uangnya) dan berat ringannya putusan yang diharapkan. Semakin tinggi bobot perkara, semakin tinggi pula kompensasinya, dan semakin ringan vonis yang dimintakan, semakin besar pula uang balas jasanya, begitu pula sebaliknya". ${ }^{39}$

Para hakim cenderung lebih mengutamakan ambisinya ketimbang misi hukum dan keadilan. Cukup banyak hakim yang telah dengan sadar menggadaikan idealismenya (cita-cita profesi) demi untuk mendapatkan uang guna memperkaya diri sendiri. "Motto perjuangan fiat justitia roeat coelum, yang artinya tegakkan keadilan meskipun langit akan runtuh, telah diselewengkan untuk 'demi uang meskipun keadilan akan hancur'." 40

Secara umum kolusi atau KKN yang berlangsung pada lembaga peradilan tidak lain adalah "persekongkolan yang dilakukan antar aparat penegak hukum dalam atau pegawai lembaga peradilan lainnya dengan pihak-pihak tertentu (penguasa, terdakwa dan atau penasehat hukumnya, pihak-pihak yang berperkara dan atau kuasa hukumnya), dalam suatu proses peradilan. Perbuatan itu dilakukan atas dasar kepentingan tertentu (memenangkan perkara, membebaskan atau memperingan hukuman atas dasar imbalan materi, hubungan kolega, atau prestasi tertentu), yang mengakibatkan proses peradilan tidak berjalan sebagaimana mestinya (tidak fair, dan tidak memenuhi rasa keadilan). ${ }^{41}$

Dalam rangkaian proses peradilan pidana yang terintegrasi, hakim merupakan subjek institusi paling akhir dari keseluruhan proses yang mesti dijalani dalam penegakan hukum kasus apapun tidak terkecuali kasus-kasus KKN. Oleh karena itu, terjadinya KKN sangat boleh jadi sudah berlangsung sejak pada tahap awal proses pemeriksaan dimulai. Aparat penegak hukum yang paling awal berkiprah dalam proses peradilan pidana adalah Polisi. Pada tahap ini para tersangka pelaku tindak pidana KKN sangat mungkin sudah melakukan upaya penyuapan terhadap oknum polisi, agar aparat penyidik dapat mengusahakan tersangka bebas atau lepas misalnya. Atau lebih jauh lagi agar oknum penyidik berusaha dengan caranya sendiri untuk mem "peti es" kan kasusnya, atau agar jangan sampai tersangka ditahan. ${ }^{42}$

Jika pertahanan moral aparat penyidik polisi cukup tangguh, setelah proses penyidikan pada tingkat kepolisian dianggap cukup, berkas perkara tindak pidana KKN akan segera dilimpahkan ke Kejaksaan. Pada

\footnotetext{
${ }^{39}$ Salman Luthan \& Agus Triyanta, "Pengembangan Sumber Daya Manusia Aparat Keadilan”; di dalam JURNAL HUKUM, No. 9 Vol. 4, 1997, hlm. (54-62) 57-58. ${ }^{40}$ Ibid., hlm. 58.

${ }^{41}$ Al. Wisnubroto, Hakim dan Peradilan di Indonesia dalam beberapa aspek kajian. Yogyakarta: Penerbitan Universitas Atma Jaya, 1997, hlm. 51.

${ }^{42}$ Ibid., hlm. 53.
} 
lingkungan aparat kejaksaan lahan untuk terjadinya suap-menyuap tidak kurang suburnya. Tidak sedikit oknum Jaksa yang pandai "bermain" dengan surat dakwaan. Bahkan jika pelaku tindak pidana $\mathrm{KKN}$ berhasil menyuap oknum Jaksa, sebagai aparat penuntut umum, oknum Jaksa yang bersangkutan akan mengusahakan hak oportunitasnya dengan dalih untuk kepentingan umum. Atau jika tidak ada alasan yang tepat, setidaknya oknum Jaksa akan mencari jalan lain, umpamanya saja dengan sengaja mengaburkan dakwaan, menuntut ringan, dan lain-lain.

Tidak dapat dipungkiri kasus terbongkarnya rekening pribadi atas nama Jaksa Agung Andi M. Ghalib yang cukup heboh beberapa waktu yang lalu merupakan salah satu bukti yang memberi indikasi telah terjadinya KKN di tubuh Kejaksaan sebagai aparat penegak hukum. Apabila pada tahap ini tersangka pelaku tindak pidana KKN berhasil menyuap oknum Jaksa, itu artinya perkara tindak pidana KKN kecil kemungkinan akan dapat dibawa ke persidangan pengadilan. Atau kalau pun perkaranya sempat dibawa ke persidangan bisa saja Jaksa menuntut agar terdakwa dibebaskan.

Meski KKN diyakini telah sangat membudaya pada masyarakat Indonesia, perbuatan KKN di lingkungan pengadilan sesungguhnya merupakan fenomena yang sangat mencemaskan proses penegakan hukum. Mengapa demikian? Oleh karena lembaga peradilan seharusnya merupakan tempat yang bebas dari wabah virus KKN. "Sulit dibayangkan lembaga peradilan dan orang-orangnya (baca: para hakim) yang seharusnya menegakkan hukum dan keadilan melalui putusannya yang berkepala "Demi Keadilan Berdasarkan Ketuhanan Yang Mahaesa", akan tetapi melakukan perbuatan yang sama dengan orang-orang yang diadilinya. ${ }^{43}$

\section{Seharusnya Komisi YudisialMendorong Reformasi Peradilan secara Komprehensif}

Dalam rangka mendorong berlangsungnya Reformasi Peradilan secara komprehensif untuk menuntaskan pemberantasan Mafia Peradilan di Lingkungan Mahkamah Agung, peran serta tugas Komisi Yudisial menjadi sangat menentukan. Tidak sekedar menjalankan rutinitas wewenang dan tugas konstitusional yang telah digariskan semata, melainkan harus lebih dari itu.

1. Apabila menengok best practicebeberapa negara di kawasan Eropa, terdapat beberapa fungsi yang mungkin bisa juga diterapkan di Indonesia. Satu di antaranya adalah bahwa Komisi Yudisial bisa juga diberikan wewenang dan terlibat secara aktif dalam penganggaran dan pengawasan administrasi peradilan. Dalam hal ini yang dimaksud dengan keterlibatan dalam penganggaran adalah keterlibatan dalam penentuan anggaran, distribusi dan alokasi, serta dalam pengawasan dan kontrol pengeluaran. Sedangkan yang dimaksud dengan pengawasan administrasi pengadilan termasuk didalamnya menyangkut beban perkara dan tumpukan perkara,

\footnotetext{
${ }^{43}$ Yasonna H. Laoly, Op. Cit., hlm. 20.
} 
arus perkara, unifikasi hukum, dan konsistensi kualitas proses pengadilan. ${ }^{44}$ Adapun terlibatnya Komisi Yudisial dalam pengawasan administrasi diharapkan menciptakan situasi check and balances sehingga administrasi pengadilan yang sangat penting dalam proses peradilan dapat berjalan secara profesional.

2. Untuk menjalankan kewenangan melakukan seleksi Hakimjudex factie, sebagaimana dimandatkan melalui 3 (tiga) Undang-undang, yakni UU Nomor 49 Tahun 2009, UU 50 Tahun 2009 dan UU 51 Tahun 2009, ternyata kewenangan Komisi Yudisial untuk kewenangan ini telah dibatalkan oleh Mahkamah Konstitusi. Para Pemohon yang adalah anggota IKAHI (Ikatan Hakim Indonesia) di bawah komando Ketua IKAHI ketika itu Imam Subechi (sekarang Mantan Ketua Kamar TUN) Mahkamah Agung.

"Berikut amar putusan Mahkamah Konstitusi secara lengkap perkara Nomor 43/PUU-XIII/2015 yang diucapkan pada tanggal 7 Oktober 2015 tersebut:

\section{Mengadili:}

Menyatakan: Mengabulkan permohonan para Pemohon untuk seluruhnya;

\section{Pertimbangannya antara lain:}

Kata "bersama" dan frasa

"dan Komisi Yudisial" dalam Ketentuan Pasal 14A ayat (2), dan ayat (3)

UU tentang Peradilan Umum, Pasal 13A ayat (2), dan ayat (3) UU tentang Peradilan Agama, Pasal 14A ayat (2), dan ayat (3) UU tentang Peradilan Tata Usaha Negara bertentangan dengan Pasal 24 ayat (1), Pasal 24B ayat (1), dan Pasal 28D ayat (1) UUD 1945 dengan alasan:

1) Keterlibatan Komisi Yudisial dalam proses seleksi pengangkatan hakim pada Peradilan Umum, Peradilan Agama dan Peradilan Tata Usaha Negara adalah inkonstitusional, karena bertentangan dengan Pasal 24 ayat (1), Pasal 24B ayat (1), dan Pasal 28D ayat (1) UUD 1945;

2) Bahwa "kekuasaan kehakiman yangmerdeka" tidak hanya dalam konteks pelaksanaan kewenangan hakim dalam memeriksa, mengadili dan memutus perkara, melainkan juga untuk melakukan proses seleksi dan perekrutan hakim yang berkualitas secara independen dan mandiri. Dengan berlakunya pasal a quo akan dapat menjadi pintu masuk bagi intervensi suatu lembaga terhadap lembaga lain yang akan merusak mekanisme checks and balances yang dibangun. Adanya keterlibatan Komisi Yudisial dalam seleksi pengangkatan hakim pengadilan negeri, pengadilan agama, dan pengadilan tata usaha negara akan merusak sistem kekuasaan kehakiman yang dijamin oleh konstitusi karena adanya "segala campur tangan dalam urusan peradilan oleh pihak lain diluar kekuasaan kehakiman dilarang, kecuali dalam hal-hal sebagaimana dimaksud dalam UUD 1945";

${ }^{44}$ Wim Voermans, Komisi Yudisialdi Beberapa Negara Uni Eropa (Terjemahan) (Jakarta: LelP dan The Asia Foundation-USAID, 2002), hlm. 11. 
3) Bahwa rumusan menyangkut keterlibatan Komisi Yudisial dalam proses seleksi pengangkatan hakim pengadilan negeri, pengadilan agama, dan pengadilan tata usaha negara, sebagaimana yang tercantum dalam ketentuan pasal-pasal a quo,menimbulkan implikasi ketidakpastian hukum dan menimbulkan persoalan konstitusionalitas."

Oleh karena itu, tampak dengan jelas bahwa judicial review terhadap tiga undang-undang yang memberikan kewenangan kepada Komisi Yudisial untuk ikut dalam seleksi hakim telah semakin memperkuat dugaan bahwa corsa para hakim tidak ingin diganggu zona nyamannya oleh lembaga mana pun di luar Mahkamah Agung.

3. Jika saja Permohonan Uji materiil atas 3 (tiga) undang-undang tentang seleksi hakim tidak dikabulkan oleh Mahkamah Konstitusi, sejatinya kewenangan Komisi Yudisial dalam menjaga dan menegakkan kehormatan dan keluhuran martabat, serta perilaku hakim itu pada hakikatnya diawali sejak pelaksanaan rekruitmen calon hakim. Ketentuan mengenai seleksi pengangkatan (rekruitmen) hakim telah diatur dalam UU No. 49 Tahun 2009 Tentang Perubahan Kedua Atas Undang-Undang Nomor 2 Tahun 1986 Tentang Peradilan Umum. Yang perlu ditegaskan dalam kesempatan ini adalah bahwa seyogianya dalam rangka proses seleksi yang fair, transparan, partisipatif, dan akuntabel, sebaiknya keterlibatan Komisi Yudisial terjadi semenjak proses perencanaan, pelaksanaan, dan evaluasi rekrutmen hakim. Dengan kata lain, dapat disebutkan bahwa Komisi Yudisial dan Mahkamah Agung bekerja secara bersama sejak dimulainya proses rekrutmen calon pegawai negeri sipil, diseleksinya calon hakim sampai dengan didapatnya para hakim baru.

4. Salah satu masalah yang selama ini timbul dan mendatangkan kesan bahwa Komisi Yudisial tidak efektif pengawasannya adalah adanya berbagai rekomendasi Komisi Yudisial yang tidak ditindaklanjuti oleh Mahkamah Agung. ${ }^{45}$ Untuk menyelesaikan masalah tersebut, ke depan sebaiknya ketentuan tentang penjatuhan sanksi ini perlu diubah, dimana untuk sanksi-sanksi yang tidak termasuk kategori berat dan memerlukan institusi Majelis Kehormatan Hakim (MKH) sebagai forum pembelaan diri bagi seorang hakim yang direkomendasi oleh Komisi Yudisial untuk dikenai sanksi berat, maka Komisi Yudisial dapat memutuskan sanksi yang dijatuhkan dan Mahkamah Agung terikat untuk mensahkan putusan Komisi Yudisial tersebut.

\section{Penutup}

Selama reformasi peradilan yang seharusnya dikawal oleh Mahkamah Agung masih dilakukan dengan setengah hati, maka selama itu pula penegakan hukum akan seperti menegakan benang basah. Mafia

45 Berdasarkan laporan akhir Komisi Yudisial periode 2005-2010 disebutkan bahwa dari 97 rekomendasi yang disampaikan Komisi Yudisial kepada Mahkamah Agung, hanya 12 yang ditindaklanjuti sedangkan sisanya sebanyak 85 rekomendasi tidak ditindaklanjuti dengan berbagai alasan. 
hukum akan tetap merajalela, karena oknum penegak hukum yang nakalakan selalau mencari peluang bagaimana caranya untuk bisa mendapat kemenangan. Oleh karena itu, nomenklatur kalah dan menang dalam berproses acara di pengadilan, baik dalam perkara perdata maupun pidana, sudah seyogianya dihapuskan, karena istilah itu membuat bias pengertian, sehingga orang yang berperkara di pengadilan, bukan mencari keadilan, akan tetapi selalu mencari kemenangan dan menghindari kekalahan.

Sepakat dengan pendapat Hakim Agung Topane Gayus Lumbuun, bahwa untuk menyelamatkan lembaga yudikatif, kiranya harus dibentuk tim evaluasi khusus yang akanmengaudit ulang permasalahan di Mahkamah Agung dan seluruh lembaga peradilan di Indonesia. Tim ini haruslah berisi orang yang kredibel dan mengikutsertakan mantan pimpinan Mahkamah Agung. Secara sederhana perlu digunakan dua syarat dasar evaluasi, yaitu syarat administrasi dan syarat latar belakang, termasuk daftar kekayaan/LHKPN. Pada gilirannya akan mudah diketahui apakah harta kekayaan para hakim/hakim agung itu diperoleh secara wajar atau tidak wajar."

Adanya asumsi bahwa sistem rekruitmen calon hakim agung dari kalangan non hakim karier akan berdampak kurang menguntungkan bagi hakim karier. Tampaknya asumsi tersebut ada benarnya juga. Persoalannya, jika hakim-hakim karier tidak diberi kesempatan yang terbuka untuk diseleksi dalam rekrutmen Hakim Agung, seberapa banyak hakim karier yang masih memiliki komitmen atas tugas-tugas mengadili serta masih menjunjung tinggi cita-cita profesi, serta masih punya integritas moral personal yang tinggi.Peluang untuk menduduki posisi sebagai hakim agung bagi para hakim karier adalah merupakan dambaan serta cita-cita mereka sejak awal menjadi hakim. Jika mereka tidak diberi kesempatan yang cukup terbuka, maka cepat atau lambat proses itu akan merupakan penjegalan atas karier seorang hakim dalam tugas pengabdiannya. Apabila itu yang terjadi, jangan salahkan mereka jika KKN di lingkungan peradilan rendahan sulit dihapuskan, malah mungkin akan semakin menjadi-jadi. Adalah merupakan konsekuensi logis dari suatu keadaan, manakala berkarier pun tak dapat lagi, bisa jadi mereka memilih untuk mengumpulkan harta sebanyak-banyaknya, meski tujuan harus menghalalkan cara.

Sudah waktunya Presiden Republik Indonesia tidak hanya mengeluarkan Paket Kebijakan Ekonomi, akan tetapi sekarang saatnya untuk mengeluarkan Paket Kebijakan Hukum dalam rangka memperbaiki Lembaga Yudikatif. Paket Kebijakan Hukum ini harus sekaligus memberi panduan konkrit tentang bagaimana memperbaiki penegakan hukum yang sudah di titik nadir ini, sehingga kembali ke alur yang benar (on the right track). Tentu saja Paket Kebijakan ini harus disertai penunjukkan orangorang yang kredibel dan memiliki track record integritas yang prima, nyaris tanpa cacat selama yang bersangkutan menduduki jabatan apa pun di Republik ini. 


\section{Daftar Pustaka}

Asshiddiqie, Jimly. Sengketa Kewenangan Antar Lembaga Negara, Jakarta, 2005.

Djohansjah, J. Reformasi Mahkamah Agung Menuju Independensi Kekuasaan Kehakiman. Bekasi Timur: Kesaint Blanc. 2008.

Fajar, Asep Rahmat Fajar. The Institutionalization of Public Participation in the Selection of Supreme Court Justices by the Judicial Commission of the Republic of Indonesia -Improving State Institution and Enhancing Civil Society-. Jakarta. 2010.

Flyvbjerg, Bent. Habermas and Foucault: Thinkers for Civil Society? The British Journal of Sociology, Vol. 49, No. 2. Blackwell Publishing. 1998.

Keputusan Bersama Ketua Mahkamah Agung dan Ketua Komisi Yudisial No: 047/KMA/SKB/IV/2009 dan No: 02/SKB/P.KY/IV/2009 tentang Kode Etik dan Pedoman Perilaku Hakim

Leawoods, Heather. Gustav Radbruch: An Extraordinary Legal Philosopher. Journal of Law \& Policy. 2000.

Lembaga Kajian dan Advokasi untuk Independensi Peradilan (LeIP), Pembatasan Perkara, Strategi Mendorong Peradilan Cepat, Murah, efisien dan berkualitas, Jakarta, 2010.

Mahfud MD, Moh. Hukum Tak Kunjung Tegak. Bandung: Citra Aditya Bakti. 2007.

-------------------, Seminar on Comparative Models of Judicial Commissions, Peran Komisi Yudisial di Era Transisi Menuju Demokrasi. Proceeding Seminar. Jakarta. 2010.

Revitalisasi Pancasila Sebagai Cita Negara Hukum. Orasi Ilmiah Rapat Senat Terbuka Fakultas Hukum Hukum Universitas Gadjah Mada dalam rangka Dies Natalis 65 Tahun Fakultas Hukum UGM, Yogyakarta. 2011.

Mahkamah Agung. Cetak Biru Pembaruan Mahkamah Agung Republik Indonesia. Jakarta: Mahkamah Agung Republik Indonesia. 2003.

Masyarakat Pemantau Peradilan Indonesia, Lembaga Pengawas Sistem Peradilan Pidana Terpadu, Jakarta: Komisi Hukum Nasional. 2002.

Pompe, Sebastiaan. The Indonesian Supreme Court: A Study of Institutional Collapse. New York: Southeast Asia Program Publication Cornel University. 2005. 
Rahardjo, Satjipto. Hukum Progresif Sebuah Sintesa Hukum Indonesia. Yogyakarta: Genta Publishing. 2009.

Rahmadi, Takdir. Peran dan Fungsi Komisi Yudisial dalam Kekuasaan Kehakiman. Proceeding Seminaron Comparative Models of Judicial Commissions, Peran Komisi Yudisial di Era Transisi Menuju Demokrasi. Jakarta, 2010.

Satuan Tugas Pemberantasan Mafia Hukum, Mafia Hukum, Jakarta: Satgas PMH-UNDP. 2010.

Sirajudin dan Zulkarnain. Komisi Yudisial \& Eksaminasi Publik Menuju Peradilan yang Bersih dan Berwibawa. Bandung: Citra Aditya Bakti. 2006.

Soetjipno. Bunga Rampai Refleksi Satu Tahun Komisi Yudisial Republik Indonesia: Komisi Yudisial dan Pengawasan Hakim. Jakarta. 2006.

Thohari, A. Ahsin. Komisi Yudisial \& Reformasi Peradilan. Jakarta: ELSAM. 2004.

Voermans, Wim. Komisi Yudisial di Beberapa Negara Uni Eropa (Terjemahan), Jakarta: LeIP dan The Asia Foundation-USAID, 2002. 